\title{
Ethnographic Patterns Map for Traditional Heritage of Kadazan Dusun Community Using GIS Analysis
}

\author{
Sieng, K. T. and Eboy, O. V. \\ Geography Programme, Faculty of Humanities, Arts and Heritage, Universiti Malaysia Sabah, Kota \\ Kinabalu, Malaysia, E-mail: kongtecksieng@gmail.com, oliver@ums.edu.my \\ * Corresponding author
}

\begin{abstract}
Ethnography is a study of languages, systems of technology, economic, social organisations, knowledge, arts, and religion. Ethnographic features are essential to be preserved for peace, a stable way of life and conserving resources and the environment. The study of ethnography in society is necessary to maintain the tradition's legacy so that future generations can practice their ancestral heritage. Recently, the needs of GIS in the ethnographic mapping field are increasing as it has its effectiveness in this field. This study was carried out to map the locations related to the ethnography of Kadazan Dusun community in Sabah, Malaysia, in spatial form using GIS application. The research data was then analysed using migration density flow map with XY To Line technique, and then density pattern was conducted using an overlay technique. The findings of this study are expected to provide exposure to the community, especially the Kadazan Dusun regarding the dissemination of ethnographic features and areas with a high ethnographic density among the Kadazan Dusun community in Tambunan. Hence it will be used as a guide to the relevant parties to perform activities of preserving the traditional heritage of the Kadazan Dusun community in Tambunan.
\end{abstract}

\section{Introduction}

In this era of globalisation, traditional legacy is an important treasure inherited from previous generations whether it presently or previously owned by the community group that collectively responsible be conserved and preserved (State Heritage Department, 2009). Other than that, it is an essential influence on our feelings, identity, loyalty, and behaviour. This will affect the individual in terms of identity, pride, and relationships with others (Gilliland et al., 2015). Currently, the activities for modernisation have raised concerns and anxieties as it threatens the traditional life of the Kadazan Dusun community. Many legacies were significantly affected by the countries development and this is detrimental to the country (Yuszaidy et al., 2013). The presence of new values that replaced ethnographic features had caused the loss of cultural identity and legacy gradually.

Consequently, the younger generation is less astute in traditional heritage because of the negative influence of the technology medium, which has dominated the minds of youngsters (National Heritage Department, 2008). Additionally, the attitude of the local community, which is less sensitive to the importance of cultural preservation had made the application of ethnographic features within themselves difficult (Latif and Sakif, 2005). Consequently, efforts to the conservation of traditional heritage are necessary and essential to ensure its sustainability in the future. In Sabah, the Kadazan Dusun community is well known for its unique ethnographic features such as language, technology systems, economic systems, social organisations, knowledge systems, arts and religious systems which are the source and inspiration of their lives (Koentjaraningrat, 1997). Because of this privilege, all parties, both government and private agencies and the Kadazan Dusun community have to shoulder the responsibility to jointly preserve or document the traditions of the Kadazan Dusun community.

Moreover, ethnographic features are important as the symbols of one's identity. The pattern mapping made in the previous study was ineffective due to the usage of only some features and it is inaccurate. Therefore, this study was conducted to improve the deficiencies in previous studies. Ethnographic mapping conducted from the previous study was minimal and unable to show various ethnographic features in a particular area. The analysis used of the prior research also was quite outdated and ineffective in explaining the distribution of the ethnographic pattern. Indeed, the ethnographic mapping produced by Livingston et al., (2016), Pearce and Louis (2006) and Lewis et al., (2017) are some of the ethnographic maps that use GIS applications to analyse and present their maps, but there are some drawbacks to them. For 
xample, the ethnographic map produced by Livingston et al., (2016) and Pearce and Louis (2006) found that they do not show various ethnographic features. In contrast, studies on ethnographic mapping by Matthews et al., (2005) did not explicitly state the location of the movement. Next, ethnographic mapping by Lewis et al., (2017) involves a large area of study where it is not specific to one district or region. Subsequently, the study question of the research is what are the distribution and pattern of the ethnographic features of the Kadazan Dusun community in Tambunan, Sabah as to identify and preserve the cultural heritage from extinct.

Finally, this study is conducted to identify the various distribution and ethnography pattern of Kadazan Dusun community in Tambunan district using GIS. The output of this study is the migration flow maps and ethnographic pattern density maps which is essential to show the distribution and ethnographic features pattern of Kadazan Dusun community in Tambunan. The migration of the Kadazan Dusun people to various places in Tambunan is crucial as it also shows how the cultural heritage distributed. Thus, this study can become a guideline for the people to maintain or identify the traditional and modern culture of the Kadazan Dusun community.

\section{Ethnography and GIS}

Ethnography is defined as a knowledge that includes research techniques, ethnographic theories, and various cultural descriptions (Spradley, 1997). According to classical anthropologist, Taylor (1871) stated that culture means the whole way of life in a society that includes knowledge, beliefs, values, morals, arts, laws, customs and other skills that learned by individuals as a member of community. While, ethnographic features include languages, systems of technology, economic systems, social organisations, knowledge systems, arts and religious systems (Koentjaraningrat 1997).

Ethnographic mapping is a process for placing, in terms of geographic space which is a place for main activities and locations of people and focus groups in a project (Tripathi et al., 2010). It plays a vital role in the study of geographical location and temporal movements of hidden populations and contrary to geographical mapping in which it can supply new information related to the changes in social, network and demographic structures within the community (Oliver et al., 2002). Ethnographic mapping was produced using reference in fieldwork notes, transcripts from ethnographic observations and semi-structured interviews with respondents
(Livingston et al., 2016). On the other hand, the Geographical Information System (GIS) is an efficient tool in preserving traditional heritage. In Kasiannan's (2006) study, the researcher has sought to show GIS as a valuable tool in mapping the tradition's legacies, especially in tradition legacies. Thus, GIS has become a popular tool to be used in cultural studies. Geographic Information Systems (GIS) also, can handle several kinds of information that can be related to a location or area (Eboy, 2017).

Indeed, only a few studies have been found which is related to the ethnographic mapping, especially in the Borneo region. Other than that, it was less accurate to represent the current scenario. Before this, the study of ethnographic mapping was deficient due to limited technology and skills. One of the reviews by Leigh (2000), regarding the ethnic mapping for each district in Sarawak, was found to be less effective because the location of each ethnic group was referred by reference number only.

\section{Research Area}

The ethnography patterns mapping of ethnic Kadazan Dusun is carried out in Tambunan. This area of study was chosen because most of the population in this area still practice traditional culture inherited by their ancestors. Besides, the district has a population of 35,667 , with more than 30,000 residents in the area are Kadazan Dusun (Department of Statistics Malaysia 2010 and Pugh Kitingan 2011). Thus, the objectives set for this study are achievable in this area. Location of the study area can be seen in Figure 1.

\section{Data of the Study}

This study was conducted based on the data from The Ethnographic and Cultural Mapping project of Sabah, Malaysia. Part 1: Tambunan District led by Pugh-Kitingan (2011). These data will be filtered through three processes: data verification and measurement, data cleaning and data format conversion before retrieving it as research data. By using the data, a GIS database comprising spatial data and attribute data will be developed. The spatial data consists of the digitised Tambunan boundary based on the Tambunan district map with a scale of 1:108,000 based on the 1976 Director of Land Survey of Sabah. The affected spatial data shows the location of the village in Tambunan, road, river and district boundary. In contrast, the attribute data is divided into ethnographic features of the Kadazan Dusun community, which consists of a set of ethnographic features of culture, development and socio-economic. 


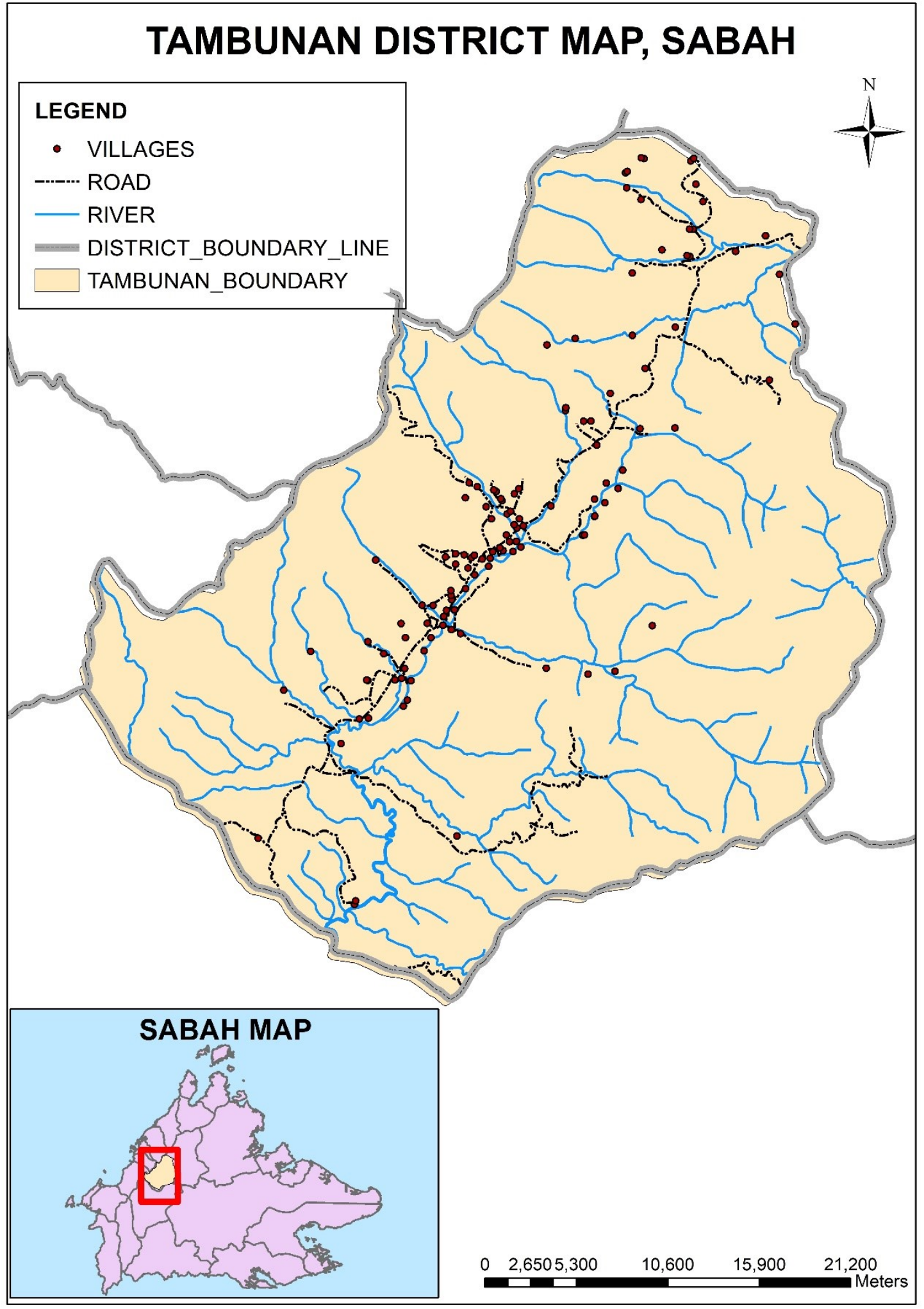

Figure 1: Study area 


\section{Method of the Study}

From the GIS data, the location of ethnography for the Kadazan Dusun community can be identified. Furthermore, GIS analysis will be conducted to determine the distribution and ethnographic patterns of the Kadazan Dusun community. The method of this study, as shown in Figure 2. Firstly, the database is developed using the data based on culture, development and socio-economy. In which the data were included in the attribute table. The data were then integrated with the spatial data using point form that function as ethnography location of Kadazan Dusun community. This ethnography location was then analysed using two types of analysis consists of pattern analysis with overlay technique and distribution analysis with flow map technique. Both outputs of these analyses were then overlay again to obtain the highest density pattern. Finally, the density map of ethnographic distribution and ethnographic pattern density will be achieved. The validation of the result of this study was conducted based on interview from two experts in the ethnography field. This method of study is capable of producing a particular density pattern that involved various ethnographic features compare with the previous research that used limited ethnographic map presentation. The data selected for analysis purpose in this study were based on the record number of 45 or below, which is $1 / 4$ from the total record. These types of data were selected as it represents a unique and variation of the data. All the data selected for this study are shown in Table 1.

\section{Analysis}

Flow map analysis techniques in ArcGIS software have been used to find out the distribution of Kadazan Dusun community's ethnographic features. Information on the origin village and current village of the population who migrated into Tambunan area is included in this analysis. Then, the location consisting of $\mathrm{X}$ and $\mathrm{Y}$ coordinates for each village was identified before the analysis of the flow map using "XY to Line" technique was conducted. While the density pattern map was analysed using spatial autocorrelation, interpolation (IDW) and overlay techniques. After selecting the data that has a record number of 45 or below, spatial autocorrelation analysis was conducted to determine the pattern based on the features and values of the data. The outcome of this analysis is clustered, dispersed or randomly. The output has to be clustered for the features to be chosen as it has to be unique. The overlay concept was used based on the diagram in Figure 3. The overlay within the same group of ethnographic features such as the cultural ethnographic features was known as low ethnographic density which was represented in yellow colour. The overlay between two groups of different ethnographic features such as the cultural and socio-economic were known as the medium density ethnography is represented in blue colour. The overlay between three groups of ethnographic features of culture, socio-economic and development was known as high ethnographic density is represented in red colour.

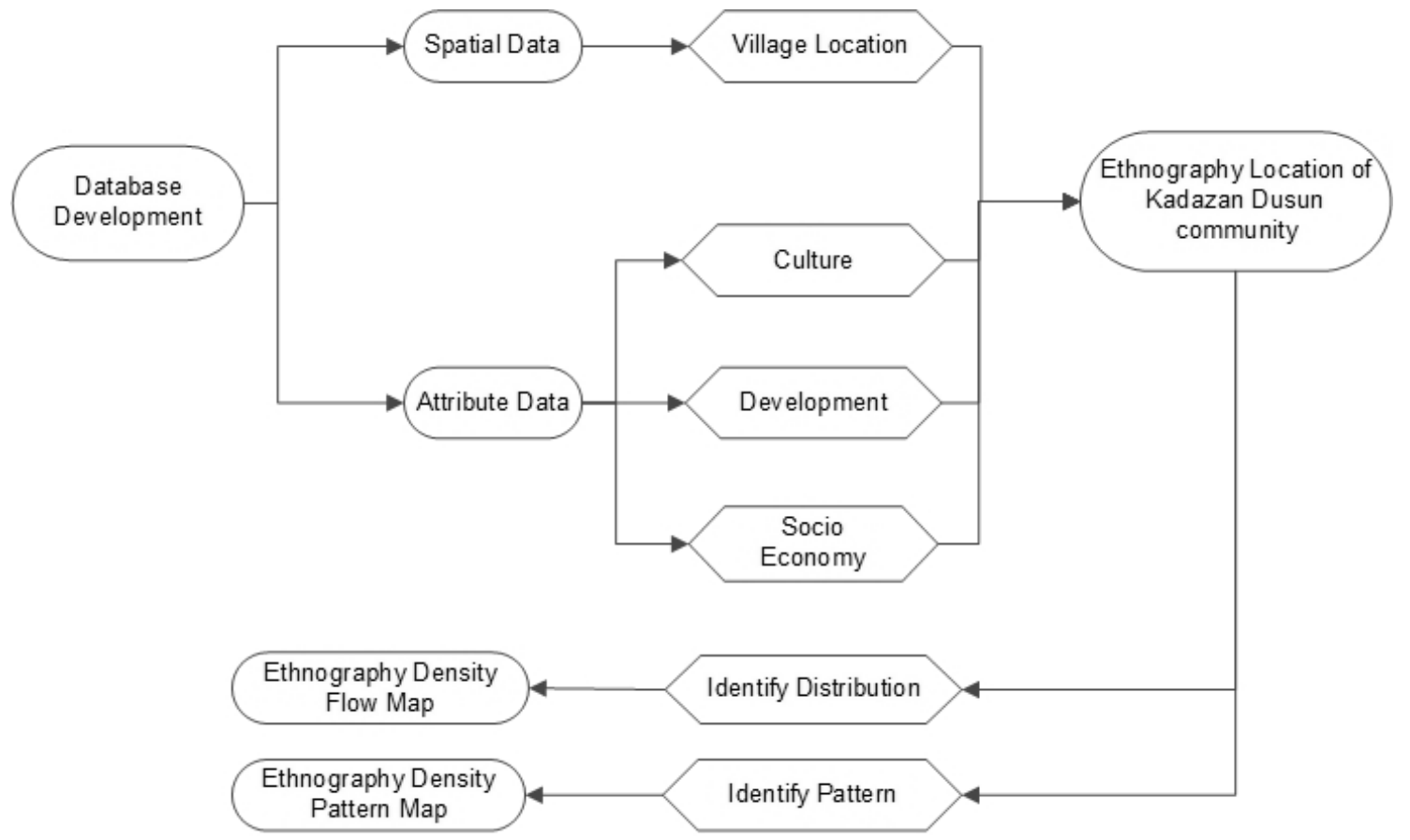

Figure 2: Method of study 
Table 1: The data used for this study

\begin{tabular}{|c|c|c|c|c|c|}
\hline No. & Ethnographic features & Description & Type & Parameter & $\begin{array}{c}\text { Ethnographic } \\
\text { Features Group }\end{array}$ \\
\hline 1. & Turali & $\begin{array}{l}\text { Traditional solo musical } \\
\text { instruments }\end{array}$ & Number & Scale & \multirow[t]{28}{*}{ Culture } \\
\hline 2. & Suling & $\begin{array}{l}\text { Traditional solo musical } \\
\text { instruments }\end{array}$ & Number & Scale & \\
\hline 3. & Kowil & $\begin{array}{l}\text { Traditional solo musical } \\
\text { instruments }\end{array}$ & Number & Scale & \\
\hline 4. & Sopogandangan & Gong & Number & Scale & \\
\hline 5. & Karatung & Tool in a gong set & Number & Scale & \\
\hline 6. & Tinindot & One kind of gong's music & Number & Scale & \\
\hline 7. & Muz_Kebumi & Burial music & Number & Scale & \\
\hline 8. & Dunsai & $\begin{array}{l}\text { Set gong music is used during } \\
\text { burial }\end{array}$ & Number & Scale & \\
\hline 9. & Togunggak & Bamboo tool sets & Number & Scale & \\
\hline 10. & Tubau & Traditional game & Number & Scale & \\
\hline 11. & Sukud & Traditional game & Number & Scale & \\
\hline 12 . & Migogol & Traditional game & Number & Scale & \\
\hline 13. & Radu & Traditional equipment & Number & Scale & \\
\hline 14. & Guyangan & Traditional equipment & Number & Scale & \\
\hline 15. & Bahaungan & A kind of basket & Number & Scale & \\
\hline 16. & Boton & A kind of basket & Number & Scale & \\
\hline 17. & Siud & A kind of basket & Number & Scale & \\
\hline 18 . & Tahum & A kind of webbing & Number & Scale & \\
\hline 19. & Hampik & A kind of webbing & Number & Scale & \\
\hline 20. & Linangkit & Traditional clothing features & Number & Scale & \\
\hline 21. & Sandai & Traditional clothing features & Number & Scale & \\
\hline 22. & Khidmat Kahwin & $\begin{array}{l}\text { A man needs to work for his in- } \\
\text { laws before marriage }\end{array}$ & Number & Scale & \\
\hline 23. & Mongoi_Siwat & $\begin{array}{l}\text { A man needs to work for his in- } \\
\text { laws before marriage }\end{array}$ & Number & Scale & \\
\hline 24. & $\begin{array}{l}\text { Membantu menanam } \\
\text { dan menuai padi }\end{array}$ & Help plant and harvest rice & Number & Scale & \\
\hline 25. & $\begin{array}{l}\text { Membantu membina } \\
\text { rumah }\end{array}$ & Help foster home & Number & Scale & \\
\hline 26. & Suhak & Present After Marriage & Number & Scale & \\
\hline 27. & Sogit & Bloody custom penalties & Number & Scale & \\
\hline 28. & Moningolig & The type of traditional ceremony & Number & Scale & \\
\hline 29. & Tadika & Kindergarten & Number & Scale & \multirow{17}{*}{ Socio-Economic } \\
\hline 30. & Tadika & Kindergarten & Number & Scale & \\
\hline 31. & Sekolah_Rendah & Primary school & Number & Scale & \\
\hline 32. & Sekolah_Menengah & Secondary school & Number & Scale & \\
\hline 33. & Klinik & Clinic & Number & Scale & \\
\hline 34. & Hospital & Hospital & Number & Scale & \\
\hline 35. & $\begin{array}{l}\text { Tidak menanam Padi } \\
\text { Baru }\end{array}$ & Not planting Padi Baru & Number & Scale & \\
\hline 36. & Kelapa & Coconut & Number & Scale & \\
\hline 37. & Kelapa Sawit & Palm oil & Number & Scale & \\
\hline 38. & Tembakau & Tobacco & Number & Scale & \\
\hline 39. & Kopi & Coffee & Number & Scale & \\
\hline 40. & Angsa & Swan & Number & Scale & \\
\hline 41. & $\begin{array}{l}\text { Memburu satu kali } \\
\text { sebulan }\end{array}$ & Hunting once a month & Number & Scale & \\
\hline 42. & $\begin{array}{l}\text { Memburu satu kali 3- } \\
6 \text { bulan }\end{array}$ & Hunting once 3-6 months & Number & Scale & \\
\hline 43. & Mendapat Payau & Got deer & Number & Scale & \\
\hline 44. & Mendapat Kijang & Got deer & Number & Scale & \\
\hline 45. & $\begin{array}{l}\text { Tempat menangkap } \\
\text { ikan }\end{array}$ & Place to catch fish & Number & Scale & \\
\hline
\end{tabular}




\begin{tabular}{|r|l|l|l|l|}
\hline 46. & Homestay & Homestay & Number & Scale \\
\hline 47. & Resort & Resort & Number & Scale \\
\hline 48. & Hidroelektrik & Hydroelectric & Number & Scale \\
\hline 49. & Bengkel motor & Motor workshop & Number & Scale \\
\hline 50. & Kilang kayu & Wood factory & Number & Scale \\
\hline 51. & Kilang perabot bambu & Bamboo furniture factory & Number & Scale \\
\hline 52. & Kilang tapai & Tapai factory & Number & Scale \\
\hline 53. & Kedai tukang jahit & Sewing shop & Number & Scale \\
\hline 54. & Kedai gunting rambut & Barber shop & Number & Scale \\
\hline 55. & Projek kraftangan & Handicraft project & Number & Scale \\
\hline 56. & $\begin{array}{l}\text { Bilangan anggota } \\
\text { professional- Doktor }\end{array}$ & $\begin{array}{l}\text { Number of professional members } \\
\text { - Doctors }\end{array}$ & Number & Scale \\
\hline 57. & $\begin{array}{l}\text { Bilangan anggota } \\
\text { professional- Peguam }\end{array}$ & $\begin{array}{l}\text { Number of professional members } \\
\text { - Lawyer }\end{array}$ & Number & Scale \\
\hline
\end{tabular}

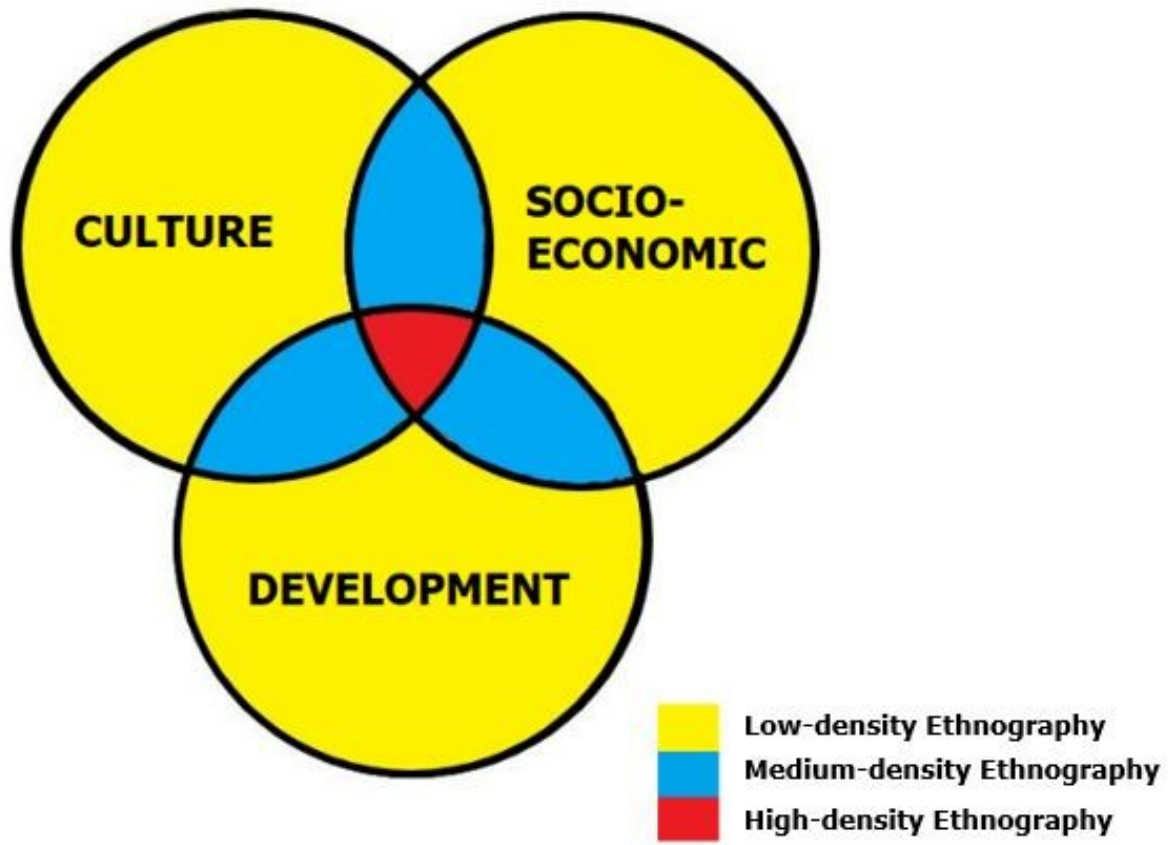

Figure 3: Concept of overlay technique

\section{Result}

In this study, the density of migration flows is used to view the distribution of ethnographic features in the area of Tambunan. Whereas the density value indicates the number of incoming and outgoing flows from the original village to the current village. The higher density value, the higher the spread of ethnographic features in Tambunan. This study produced a migration flow map in Tambunan with a density value of four and five. Density four means the current village receives migration from four origin villages, while the five density is migration from five origin villages.

The migration flow map with a density value of four and five is shown in Figure 4. The density four migration flow map involving villages of Tangaban and Kiawayan while the density five migration flow map includes village of Monsorulung only. Thus, based on the result, the village of Monsorulung is the village that receives the most influx of migration flows in which five villages migrate and settle in Monsorulung village. It is followed by Tangaban and Kiawayan village in which migration flows from four villages. Furthermore, this study also produced an ethnographic density pattern map, as shown in Figure 5. This density map consists of low-density pattern areas represented in yellow colour, medium density pattern represented in blue and high-density pattern represented in red. Overall, most of the pattern that produced were clustered. From the map, a large group of clustered patterns concentrated in central of Tambunan. The reason may be influenced by the location of Tambunan, which is located at the central part of Tambunan. 


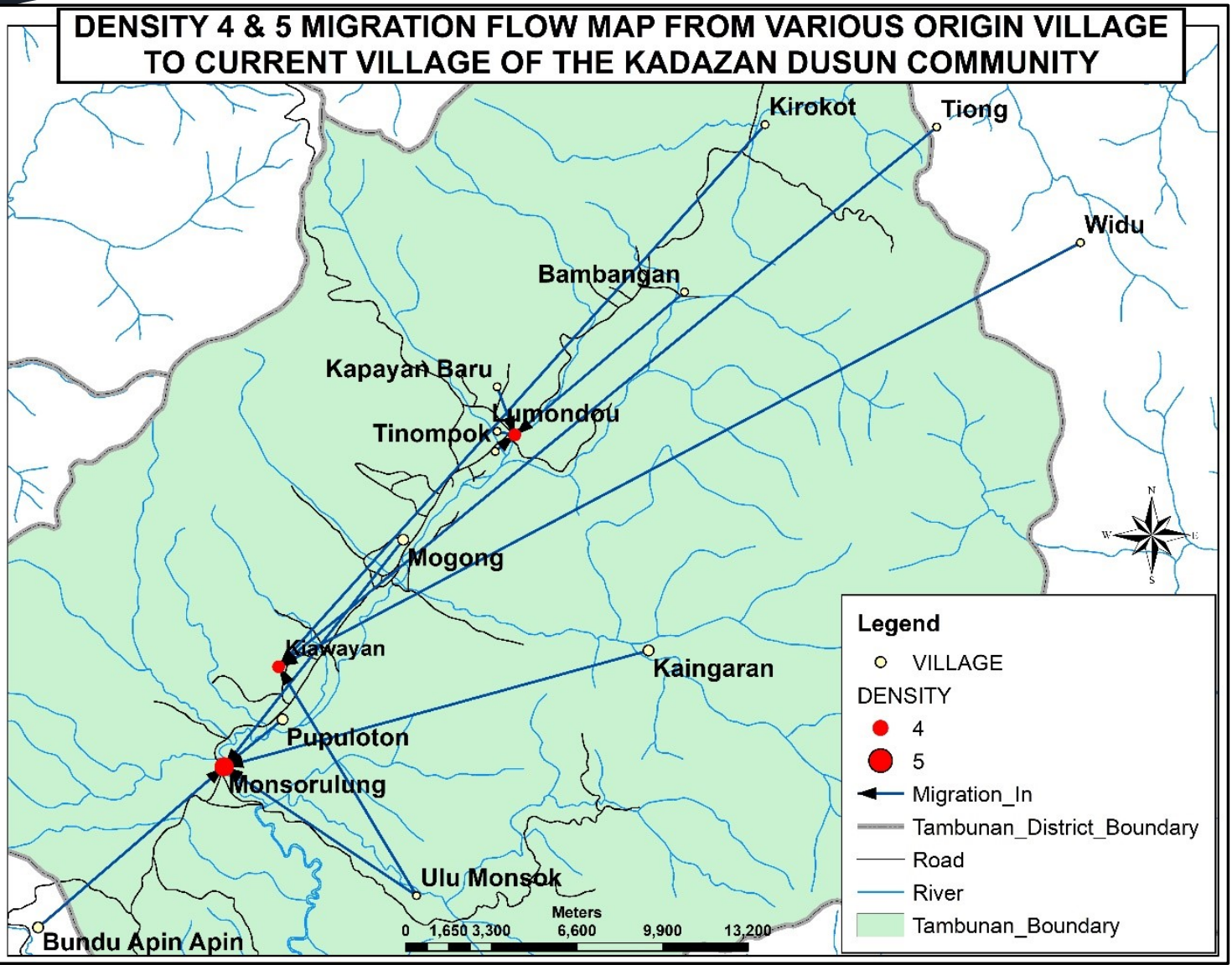

Figure 4: Density $4 \& 5$ migration flow map from various origin village to current village of the Kadazan Dusun community in Tambunan

These areas involve villages such as Piasau, Noudu, Tondulu, Lubang, Nambayan, Toboh, and Kuala Kaingaran. In the northern part of the Tambunan district, the area with clustered patterns of ethnographic features is smaller compared to other areas. It has fewer villages such as Kirokot, Lubang, Garas, and Tontolob Liwan.

Furthermore, the southern and eastern area of Tambunan has less or no ethnographic features with high variation. The pattern is more dispersed around the area of villages such as Tikolod, Kuala Monsok, and Ulu Monsok. Overall, based on the analysis, the development of ethnographic features has a significant influence on the high-density pattern in Tambunan. Ethnographic features such as homestays, factories, and sewing shops were not many in Tambunan. Therefore, the area size for high density is smaller compared to the medium density and low density. Subsequently, the discussion of the results for this study is more focused on the highdensity area as it has more ethnographic features with different variants. This study also identifies the intersection between the high density of migration flow and the high-density pattern of ethnographic features. The outcome shows that Kiawayan village received the highest density for migration flow and high-density pattern of ethnographic features.

\section{Discussion}

Based on the findings from the flow map that conducted using $\mathrm{XY}$ to Line, the distribution of ethnographic features of the Kadazan Dusun community is due to the migration of villagers into Tambunan. In reality, several factors are affecting this inflow migration. For Monsorulung village, the factor of rich with land which can be used for agriculture activities encourages inflow migration. While for Kiawayan and Tangaban villages, the factors that encourage inflow migration are fertile rice field to carry out paddy rice cultivation activities, vast land to cultivate for the livelihood of the villagers and moving into husband's family after marriage. Subsequently, villages within the highdensity area have a high and unique ethnographic feature of Kadazan Dusun community. The uniqueness of high-density pattern areas is shown based on ethnographic features in Table 2. 


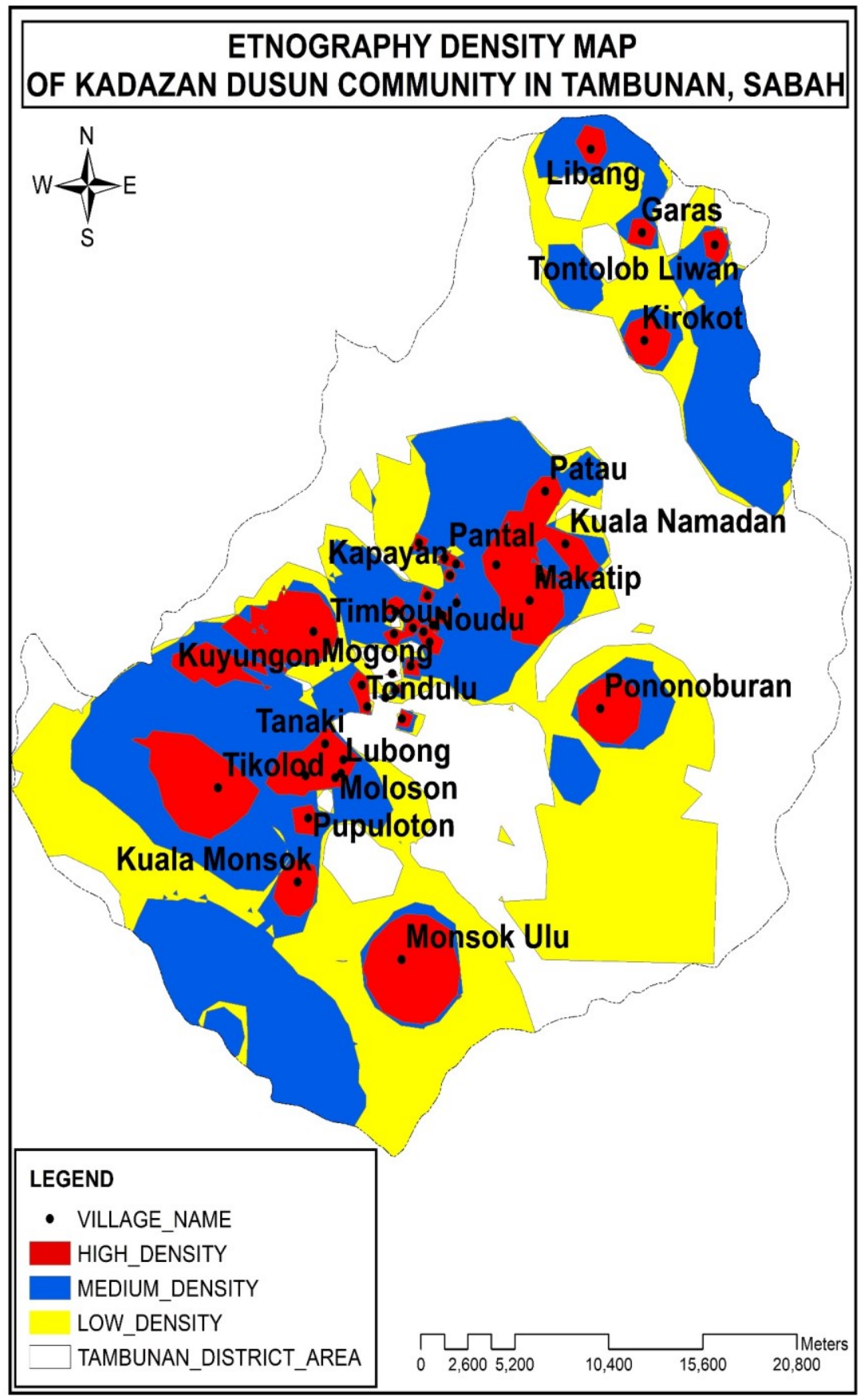

Figure 5: Ethnography Density Map of Kadazan Dusun Community in Tambunan, Sabah

Therefore, with the supporting statements from Table 2, it is undeniable that this high-density area has a high and unique ethnographic feature. As for Kiawayan village which has both high density for migration flows and ethnographic pattern, it shows that this village is rich in ethnographic features and needs to be preserved. Indeed, Kiawayan village has unique features of ethnography such as having a vast and fertile rice field to produce paddy or rubber paddy fields with good irrigation sources for paddy fields (Pugh-Kitingan, 2018) (Judeth, 2018). Meanwhile, in terms of culture, Kiawayan village is unique because it has a higher number set of gong compared to the other villages (Pugh-Kitingan, 2018). The higher number of gong set would enable the gong to produce better sound. Other than that, this village is also equipped with road facilities that can increase the level of community delivery here.

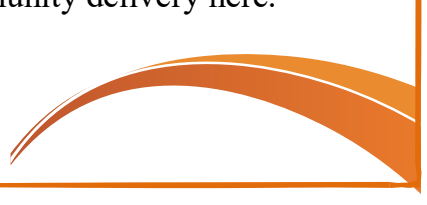


Table 2: The uniqueness of high-density pattern areas

\begin{tabular}{|c|c|c|}
\hline $\begin{array}{l}\text { Ethnographic } \\
\text { Features Group }\end{array}$ & High-Density Pattern Area & Village Involved \\
\hline \multirow[t]{3}{*}{ Culture } & $\begin{array}{l}\text { - Centre of original music instruments such } \\
\text { as Tongkungon and Sompoton. }\end{array}$ & - $\quad$ Tikolod village \\
\hline & $\begin{array}{l}\text { - Centre to develop textiles and beads } \\
\text { traditionally. }\end{array}$ & - $\quad$ Kuala Monsok \\
\hline & $\begin{array}{l}\text { - It has the privilege of having more gong } \\
\text { set numbers than any other village. }\end{array}$ & $\begin{array}{ll}- & \text { Toboh } \\
\text { - } & \text { Lintuhun } \\
\text { - } & \text { Nambayan } \\
\text { - } & \text { Kiawayan } \\
\end{array}$ \\
\hline \multirow[t]{3}{*}{ Socio Economy } & $\begin{array}{l}\text { Produced hydroelectric generating } \\
\text { machines using the Kancil car engine. }\end{array}$ & $\begin{array}{ll}- & \text { Kirokot } \\
- & \text { Moloson }\end{array}$ \\
\hline & $\begin{array}{l}\text { Contribute to the production of tobacco, } \\
\text { ginger, pond fish, and oil palm. }\end{array}$ & $\begin{array}{ll} & \text { Moloson } \\
\text { - } & \text { Tikolod } \\
\text { - } & \text { Kuala Monsok } \\
\text { - } & \text { Pagalan Kusob } \\
\text { - } & \text { Pupuloton } \\
\text { - } & \text { Lumbayan } \\
\text { - } & \text { Kiawayan } \\
\end{array}$ \\
\hline & - Wood factory & - Karanaan \\
\hline \multirow[t]{3}{*}{ Development } & \multicolumn{2}{|c|}{$\begin{array}{l}\text { Have complete facilities such as roads, electricity, water, schools, } \\
\text { infrastructure, factories, shops, government offices and others }\end{array}$} \\
\hline & - $\quad$ Resort that provides homestay and chalet & $\begin{array}{ll}\text { - Kuala Kaingaran } \\
\text { - Kapayan } \\
\text { Karanaan }\end{array}$ \\
\hline & $\begin{array}{l}\text { - Produce human capital such as artists and } \\
\text { politicians }\end{array}$ & $\begin{array}{ll}\text { - } & \text { Karanaan } \\
\text { - } & \text { Toboh } \\
\end{array}$ \\
\hline
\end{tabular}

GIS analysis which included XY To Line techniques and overlay have been highlighted as the main analytical techniques in ethnographic pattern mapping. The combination of these methods capable of producing a better ethnographic map by showcased the highest density of the various ethnography features of the Kadazaan Dusun community. This result is far better than the previous study conducted by Livingston et al., (2016), Pearce and Louis (2006) and Lewis et al., (2007) as they only use one type of ethnography features and unable to show the kind of ethnographic density in their study area.

\section{Conclusion}

In conclusion, the preservation of the cultural heritage of the Kadazan Dusun community to enrich and educate generations of present and future is essential. In this study, the introduction of GIS in the field of mapping helped to produce a map of ethnographic patterns that indirectly maintain the heritage of the Kadazan Dusun community. The ethnographic map highlighted from this study shows various ethnographic features that can be a useful tool to describe the Kadazan Dusun community's heritage. The features based on the local musical instruments, the costumes, the handicraft to the local inventions, which is fast disappearing from the new generations can be preserved by documented it through maps. With the ethnographic map, highdensity ethnographic features can be identified and become the focus area for relevant authorities to protect and maintain the traditional heritage of the Kadazan Dusun community. Other than that, the concept introduced in this study by overlaying the three types of ethnographic features is something new that can be used by future researchers who wish to conduct ethnographic mapping study. In this study, the overlay technique was conducted for the ethnographic features of culture, socio-economic and development to identify the level of density around the area of Tambunan. The improvement of this concept can be made by adding more ethnographic features type into the overlay technique provided that the data is available.

\section{Acknowledgements}

Authors would like to thank Universiti Malaysia Sabah for providing financial support to complete this study and to those who contribute their knowledge and experience to validate the result of this study. 


\section{References}

Department of Statistics Malaysia, 2010, Total Population by Ethnic Group, (Malaysia Administrative District and State).

Eboy, O. V., 2017, Tourism Mapping: An Overview of Cartography and the Use of GIS. Bimp-Eaga Journal for Sustainable Tourism Development, Vol 6(1), 61-67.

Gilliland, E. M., Tomi, A. J. M. and Buckland, M., 2015, Cultural Heritage (Patrimony): An Introduction. Archives and Memory Studies, 1125.

Judeth, J. B., 2018, Personal Communication. Director of Academic Department in Sabah Museum. Sabah Museum. 27 July 2018.

Kasiannan, 2006, Mapping Traditional Belief Systems and Establishing Contemporary Connections in A Historical Landscape. XXI International CIPA Symposium, 01-06 October, Athens, Greece. 1-6.

Koentjaraningrat, 1997, People and Culture in Indonesia, (Jakarta: Djambatan).

Latif, F. A. A. and Sakif, M. S. F., 2005, Preservation and Conservation of Cultural Landscapes Kampung Melayu. Case Study: Duyong Island Village, Kuala Terengganu, (Shah Alam: Institute of Research, Development and Commercialization of University Technology Mara).

Leigh, M., 2000, The Population of Sarawak: Baseline Mapping of Rural Ethnic Distribution Prior To The New Economic Policy, (Kuching: Universiti Malaysia Sarawak).

Lewis, M. Paul, Simons, G. F. and Fennig, D. D., 2017, Ethnologue: Languages of the World, Eighteenth edition. Dallas, Texas: SIL International. Online: http://www.ethnologue.com. Accessed on $10^{\text {th }}$ January 2018.

Livingston, K., Mark, P., Derrick S., Jose, F. C., Armando, M. R. and Nelson, V., 2016, Methods of Mapping Ethnographic Data on Migration, Tourism Labor, and Health Risk in The Dominican Republic. Fla Geogr, Vol. 47. 1-14.

Matthews, S. A., Detwiler, J. E., Burton, L. M., Matthews, S. A., Detwiler, J. E., and Burton, L. M., 2005, Geo-ethnography: Coupling Geographic Information Analysis Techniques with Ethnographic Methods in Urban Research Cartographica The International Journal for Geographic Information and Geovisualization, Vol. 40(4), 75-90.

National Heritage Department, 2008, Historic Cities of Straits of Malacca: Melaka And Georgetown Towards World Heritage Listing, (Kuala Lumpur: Ministry of Unity, Culture, Arts and Heritage).

Oliver, V. D., Finlinson, H. A., Deren, S., Robles, R. R. and Colon, H., 2002, Mapping the AirBridge Locations: The Application of Ethnographic Mapping Techniques to a Study of HIV Risk Behavior Determinant. Human Organization, Vol. 61(3), 262-272.

Pearce, M. and Louis, R., 2008, Mapping Indigenous Depth of Place. American Indian Culture and Research Journal, Vol. 32(2), 107126.

Pugh-Kitingan, J., 2011, Report on the Project "The Ethnographic and Cultural Mapping of Sabah, Malaysia. Part 1: Tambunan District". Borneo Research Bulletin, Vol. 42, 233-247.

Pugh-Kitingan, J., 2018, Personal Communication. Lecturer of Programme Antropology and Sociology UMS, Faculty of Humanities, Art and Heritage, Universiti Malaysia Sabah, 26 July 2019.

Spradley, J. P., 1997, Ethnography Method, (Yogyakarta: Misbah Zulfa Elizabeth, Tiara Wacana).

State Heritage Department, 2009, Traditional Legacy, (Kuala Lumpur: Department of National Heritage).

Taylor, E. B., 1871, Primitive Culture: Researches into the Development of Mythology, Philosophy, Religion, Language, Art, and Custom, (London: Bradbury, Evans, and Co., Printers, Whitefriars).

Tripathi, B. M., Sharma, H. K., Pelto, P. J. and Tripathi, S., 2010, Ethnographic Mapping of Alcohol Use and Risk Behaviors in Delhi. AIDS and Behavior, Vol.14(1), 94 - 103.

Yuszaidy, M. Y., Hanapi, D. and Ab Samad, K., 2013, Heritage Property Protection: Effectiveness of Conservation and Preservation Efforts in National Development. Malaysian Journal of Society and Space, Vol. 9(2), 64 - 77. 